\title{
EFEK VARIASI DAYA IRADIASI GELOMBANG MIKRO TERHADAP KARBON AKTIF TONGKOL JAGUNG UNTUK PENJERNIHAN AIR
}

\author{
Raysa Fadillah ${ }^{1, *}$, Rakhmawati Farma ${ }^{2}$, Awitdrus ${ }^{2}$ \\ ${ }^{1}$ Mahasiswa Program Studi S1 Fisika ${ }^{1}$ \\ ${ }^{2}$ Dosen Jurusan Fisika ${ }^{2}$ \\ Fakultas Matematika dan Ilmu Pengetahuan Alam \\ Universitas Riau Kampus Bina Widya \\ J1. Prof. Muchtar Luthfi Pekanbaru, 28293, Indonesia \\ *E-mail: raysafadillah24@gmail.com
}

\begin{abstract}
The power of microwave irradiation affect the quality of activated carbon. In this research the activated carbon has been made of biomass of corn cob by using carbonization process, chemical activation using potassium hydroxide as the activating agent and microwave irradiation power was variated for 360 watt, 450 watt, 630 watt, dan 720 watt in 15 minutes. The surface morphology of activated carbon for the sample KA720 produced lots of pores more than that of the sample KA360, KA450, and KA630. The sea water that has been mixed with activaed carbon using microwave irradiation power of 720 watt with temperatur of $26^{\circ} \mathrm{C}$, and $\mathrm{pH}$ of 7,41 .
\end{abstract}

Keywords: Corn cob, activated carbon, potassium hydroxide, microwave, adsorption, sea water.

\begin{abstract}
ABSTRAK
Daya iradiasi gelombang mikro dapat berpengaruh terhadap kualitas karbon aktif. Pada penelitian ini karbon aktif dibuat berbahan dasar biomassa tongkol jagung dengan melalui proses pra-karbonisasi, aktivasi kimia menggunakan aktivator kalium hidroksida dan iradiasi gelombang mikro dengan variasi daya 360 watt, 450 watt, 630 watt, dan 720 watt selama 15 menit. Morfologi permukaan karbon aktif untuk sampel KA720 menghasilkan jumlah pori-pori lebih banyak dibandingkan dengan sampel KA360, KA450, dan KA630. Air laut yang telah diberikan karbon aktif dengan daya iradiasi gelombang mikro sebesar 720 watt mamiliki suhu $26^{\circ} \mathrm{C}$, dan pH sebesar 7,41 .
\end{abstract}

Kata Kunci: Tongkol jagung, karbon aktif, kalium hidroksida, iradiasi gelombang mikro, adsorpsi, air laut.

\section{PENDAHULUAN}

Indonesia terdiri dari pulau-pulau besar dan kecil yang jumlahnya kurang lebih 17.504 pulau dengan panjang garis pantai $95.151 \mathrm{~km}$. Akibat dari wilayah negara Indonesia yang merupakan negara kepulauan, banyak masyarakat Indonesia yang tinggal di pesisir pantai [1]. Masyarakat yang tinggal di daerah pesisir pantai banyak yang masihsusah untuk mendapatkan air bersih. Upaya yang dapat dilakukan untuk memenuhi kebutuhan air bersih di daerah pesisir yaitu dengan cara memanfaatkan air laut, agar dapat dimanfaatkan air laut harus diolah terlebih dahulu [2].
Proses adsorbsi merupakan salah satu metode pengolahan air secara fisika yang telah banyak dikembangkan. Adsorbsi merupakan proses peyerapan zat pengotor yang terdapat pada air sehingga air menjadi bersih. Metode adsorbsi menggunakan karbon aktif sebagai bahan penyerapan (adsorben) [3].

Jagung dengan nama ilmiah Zea mays $\mathrm{L}$ adalah salah satu makanan pokok sumber karbohidrat pengganti nasi yang mudah dijumpai di pasaran. Kandungan yang terdapat pada tongkol jagung seperti selulosa sebanyak $41 \%$, hemiselulosa sebanyak $36 \%$ dan lignin sebanyak $6 \%$ menandakan bahwa tongkol jagung berpotensi dan efektif digunakan sebagai bahan pembuat karbon aktif, selain itu kadar abu yang 
terdapat pada tongkol jagung juga cukup rendah yaitu sebesar $1,50 \%$ [4].

Berdasarkan uraian latar belakang tersebut maka penelitian ini dilakukan yang bertujuan untuk mengetahui pengaruh variasi daya iradiasi gelombang mikro terhadap struktur mikro, morfologi permukaan, luas permukaan, dan daya serap karbon aktif yang dihasilkan. Karbon aktif dibuat dari tongkol jagung dan diaktivasi dengan proses aktivasi kimia menggunakan aktivator $\mathrm{KOH}$ sebanyak $5 \%$ yang selanjutnya dilakukan iradisi gelombnag mikro dengan variasi daya 360 watt, 450 watt, 630 watt, dan 720 watt. Pengujian dilakukan pada air laut yang berada di daerah Dumai serta sifat fisis dan kimia air laut yang akan diketahui yaitu kandungan logam berat nikel (Ni), timbal $(\mathrm{Pb})$, seng $(\mathrm{Zn})$, warna, $\mathrm{pH}$, suhu dan salinitas air laut.

\section{METODE PENELITIAN}

Tongkol jagung yang digunakan adalah tongkol jagung yang berasal dari limbah pertanian yang diambil dari daerah Simpang Empat kabupaten Pasaman Barat provinsi Sumatra Baratberjenis Hibrida - NK 7328 yang berumur 4 bulan.Tongkol jagung yang sudah bersih dijemur dibawah sinar matahari untuk mengurangi kandungan air yang terdapat pada tongkol jagung. Proses penjemuran dilakukan hingga tongkol jagung memiliki massa yang konstan kurang lebih selama 3-5 hari. Tongkol jagung yang benarbenar kering dan telah memiliki massa yang konstan, maka proses selanjutnya dilanjutkan ke tahap prakarbonisasi.

Proses pra-karbonisasi dilakukan menggunakan oven listrik selama 4 jam pada suhu $200^{\circ}$ C. Setelah proses pra-karbonisasi karbon digerus dan diayak menggukan ayakan 100.Tahap pembuatan karbon aktif berikutnya yaitu tahap aktivasi. Tahap aktivasi yaitu proses pengaktifan karbon yang bertujuan untuk memperbesar pori dan luas permukaan karbon aktif kemudian akan berpengaruh terhadap jumlah dan struktur pori-pori karbon aktif kemudian daya serap karbon aktif akan meningkat. Aktivasi yang dilakukan yaitu dengan proses aktivasi kimia menggunakan aktivator kalium hidroksida $(\mathrm{KOH})$. Aktivasi kimia dilakukan dengan menggunakan air suling sebanyak $300 \mathrm{~mL}$ yang diletakkan didalam gelas beaker. Padatan $\mathrm{KOH}$ ditimbang sebanyak 5\% dari berat karbon kemudian masukkan karbon yang telah halus sebanyak 30 gram. Tutup gelas beaker dengan menggunakan alumunium foil kemudian aduk sampel dengan menggunakan Hot Plate dan Magnetic Stirrer pada suhu ruang $\left(30^{\circ} \mathrm{C}\right)$ dengan kecepatan $400 \mathrm{rpm}$ selama 20 jam.

Karbon aktif yang telah di aktivasi kemudian dilakukan proses iradiasi gelombang mikro dengan menggunakan oven microwave. Proses iradiasi gelombang mikro ini dapat juga disebut dengan proses aktivasi fisika. Karbon aktif yang telah dilakukan perendaman dengan aktivator $\mathrm{KOH}$ kemudian diiradiasi dengan daya bervariasi sebesar 340 watt, 450 watt, 630 watt, 720 watt dan waktu iradiasi selama 15 menit. Proses iradiasi dibantu dengan mengaliri gas nitrogen $\left(\mathrm{N}_{2}\right)$ untuk mengurangi terbentuknya abu pada karbon aktif yang dihasilkan.

Tahap terakhir dalam pembuatan karbon aktif dari tongkol jagung ini yaitu proses pencucian dan pengeringan. Tahap pencucian dilakukan dengan menggunakan air suling.Karbon aktif direndam dengan menggunakan air suling secara berulang-ulang hingga mencapai $\mathrm{pH}$ netral ( $\mathrm{pH}$ 7).Pengukuran $\mathrm{pH}$ dilakukan pada saat penggantian air suling dengan menggunakan kertas lakmus, jika pH karbon aktif belum netral maka air suling harus diganti setiap pagi dan petang. Setelah karbon aktif mencapai $\mathrm{pH}$ netral proses selanjutnya yaitu pengeringan karbon aktif dengan menggunakan oven listrik pada suhu $100^{\circ} \mathrm{C}$ selama \pm 24 jam.

\section{HASIL DAN PEMBAHASAN}

Karbon aktif tongkol jagung dibuat dengan beberapa tahap yaitu pengeringan, pra-karbonisasi, aktivasi kimia, dan iradiasi gelombang mikro. Pengeringan dilakukan dengan cara menjemur tongkol jagung di bawah sinar matahari hingga tongkol jagung memiliki massa yang konstan. Penjemuran bertujuan untuk mengurangi kadar air yang terdapat pada tongkol jagung sehingga pembakaran tongkol jagung 
pada saat proses pra-karbonisasi lebih efisien. Proses pra-karbonisasi bertujuan untuk menguraikan bahanbahan organik yang terdapat pada tongkol jagung seperti selulosa, hemiselulosa, dan lignin menjadi unsur karbon [5]. Pra-karbonisasi dilakukan dengan cara membakar tongkol jagung dengan menggunakan oven listrik pada suhu $200^{\circ} \mathrm{C}$ selama 4 jam. Tongkol jagung sebelum dan setelah proses pra-karbonisasi dapat dilihat pada Gambar1.

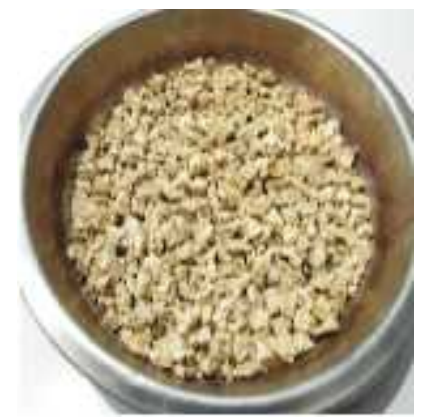

(a)

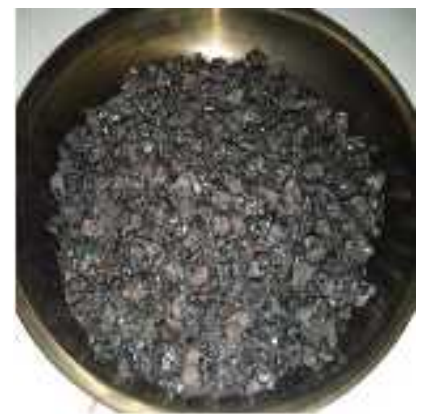

(b)
Gambar 1. Tongkol Jagung (a) Sebelum prakarbonisasi, (b) Setelah pra-karbonisasi.

Suhu pra-karbonisasi menyebabkan perubahan warna pada karbon aktif jika dilihat secara visual dimana semakin tinggi suhu yang digunakan maka warna karbon aktif akan terlihat semakin hitam dan gelap, hal ini terjadi karena senyawa-senyawa non karbon telah terurai selama proses pra-karbonisasi dilakukan [6].

Gambar 1 menunjukkan bahwa tongkol jagung mengalami perubahan warna setelah dilakukan proses pra-karbonisasi dimana sebelum pra-karbonisasi tongkol jagung terlihat bewarna putih kekuningan dan setelah dilakukan pra-karbonisasi tongkol jagung menjadi berwarna coklat kehitaman. Proses prakarbonisasi menyebab-kan terjadinya penyusutan massa pada tongkol jagung. Tongkol jagung sebelum dilakukan proses pra-karbonisai ditimbang terlebih dahulu kemudian dilakukan pra-karbonisasi, setelah pra karbonisasi selesai tongkol jagung juga kembali ditimbang, hal ini dilakukan untuk mengetahui besar penyusutan massa tongkol jagung. Persentase penyusutan massa tongkol jagung sebelum dan setelah proses pra-karbonisasi dapat dilihat pada Tabel 1 .
Tabel 1 menunjukkan rata-rata penyusutan massa tongkol jagung setelah proses pra-karbonisasi yaitu sebesar 53,48 \%. Tongkol jagung yang awalnya memiliki massa total 390 gram setelah dilakukan prakarbonisasi berkurang menjadi 181,41 gram. Penyusutan massa tongkol jagung pada proses prakarbonisasi ini disebabkan hilangnya kandungan air dan terurainya bahan-bahan organik yang terdapat pada tongkol jagung menjadi unsur karbon. Pemanasan yang diberikan pada saat proses prakarbonisasi dapat menghilangkan komponenkomponen yang terkandung pada biomassa yang digunakan sehingga hanya tersisa karbonnya saja [7].

Karakterisasi karbon aktif dilakukan untuk mengetahui yield karbon aktif, struktur mikro, morfologi permukaan, luas permukaan, dan daya serap karbon aktif terhadap logam berat serta sifat fisis dan kimia air laut.

\section{Yield karbon aktif}

Proses iradiasi gelombang mikro ini bertujuan untuk mengoptimalkan kerja dari $\mathrm{KOH}$ sebagai aktivator sehingga pori-pori karbon aktif menjadi lebih banyak dan terbuka untuk meningkatkan daya serapnya. Proses iradiasi gelombang mikro dapat juga dikatakan sebagai proses aktivasi fisika karena daya yang digunakan pada saat proses iradiasi akan menimbulkan temperatur yang tinggi, hal ini sangat membantu untuk pembetukan pori pada karbon aktif sehingga pori-pori akan semakin banyak dan luas permukaan karbon aktif akan meningkat [8].

Karbon aktif sebelum dan setelah dilakukan iradiasi gelombang mikro ditimbang untuk mendapatkan nilai yield karbon aktif. Yield karbon aktif dengan variasi daya iradiasi gelombang mikro untuk sampel KA360, KA450, KA630 dan KA720 dapat dilihat pada Gambar 2.

Gambar 2 menunjukkan bahwa semakin besar daya yang digunakan pada proses iradiasi maka semakin berkurang karbon aktif yang dihasilkan sehingga persentase yield karbon aktif juga akan semakin berkurang, hal ini dikarenakan semakin besar daya yang digunakan maka panas yang dihasilkan 
akan semakin besar sehingga terjadi penyusutan kadar air, penyusutan bahan non-karbon dan pembentukan pori-pori secara maksimum yang terdapat pada karbon aktif [8]. Penyusutan kadar air dan bahan non-karbon menyebabkan persentase yield karbon aktif semakin kecil seiring dengan bertambahnya daya iradiasi yang diberikan, akan tetapi pada sampel KA630 yield karbon aktif menurun karena pada saat proses iradiasi gelombang mikro timbul percikan api yang menyebabkan sampel terbakar dan tumpah yang mengakibatkan sampel yang dihasilkan menjadi jauh berkurang.

Tabel 1 Persentase susut massa tongkol jagung.

\begin{tabular}{|c|c|c|c|}
\hline \multirow{2}{*}{$\begin{array}{c}\text { Pra- } \\
\text { karbonisasi } \\
\text { ke- }\end{array}$} & \multicolumn{2}{|c|}{$\begin{array}{c}\text { Massa Tongkol } \\
\text { Jagung }\end{array}$} & \multirow{2}{*}{$\begin{array}{c}\text { Persentase } \\
\text { Penyusutan } \\
\text { Massa(\%) }\end{array}$} \\
\hline & $\begin{array}{l}\text { Sebelum } \\
\text { (gram) }\end{array}$ & $\begin{array}{l}\text { Setelah } \\
\text { (gram) }\end{array}$ & \\
\hline 1 & 30 & 14,18 & 52,73 \\
\hline 2 & 30 & 14,75 & 50,83 \\
\hline 3 & 30 & 16,00 & 46,67 \\
\hline 4 & 30 & 12,09 & 59,70 \\
\hline 5 & 30 & 12,61 & 57,96 \\
\hline 6 & 30 & 14,74 & 50,86 \\
\hline 7 & 30 & 13,61 & 54,63 \\
\hline 8 & 30 & 14,50 & 51,67 \\
\hline 9 & 30 & 14,17 & 52,76 \\
\hline 10 & 30 & 13,73 & 54,23 \\
\hline 11 & 30 & 13,55 & 54,83 \\
\hline 12 & 30 & 13,00 & 56,67 \\
\hline 13 & 30 & 14,48 & 51,73 \\
\hline \multicolumn{2}{|c|}{ Rata-Rata } & \multicolumn{2}{|c|}{53,48} \\
\hline
\end{tabular}

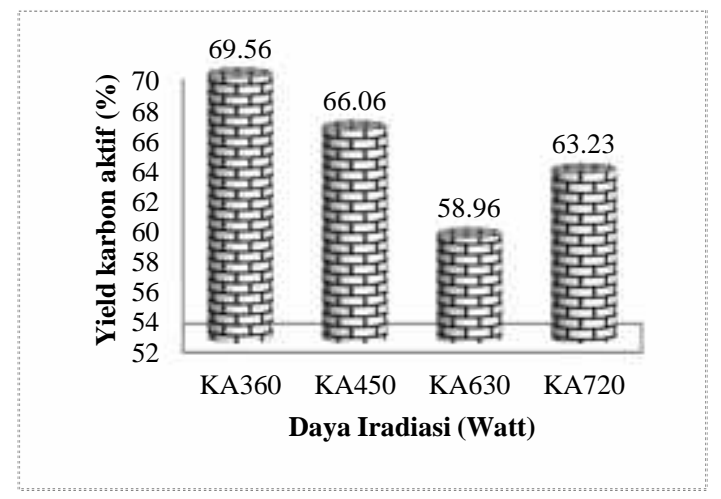

Gambar 2.Yield karbon aktif.

\section{Analisa Scanning Electron Microscopy}

Morfologi permukaan karbon aktif tongkol jagung yang dapat diketahui dengan cara melihat bentuk permukaan, ukuran dan distribusi pori dengan menggunakan Scanning Electron microscopy (SEM). Gambar 3 menunjukkan morfologi permukaan karbon aktif tongkol jagung dengan variasi daya iradiasi gelombang mikro. Morfologi permukaan sampel KA360 ditunjukkan pada Gambar 3 (a) terlihat bahwa pori-pori yang dihasilkan masih sedikit dan tertutup olah zat-zat pengotor, sedangkan pada Gambar 3 (b) untuk sampel KA450 pori-pori terlihat lebih banyak dan semakin membesar, akan tetapi pada Gambar 3 (c) untuk sampel KA630 pori-pori karbon aktif terlihat sedikit dibandingkan dengan sampel KA360, KA450, dan KA720 karena pada saat pemberian daya iradiasi sebesar 630 yang tidak maksimal. Sampel KA720 adalah karbon aktif yang memiliki pori yang paling banyak.
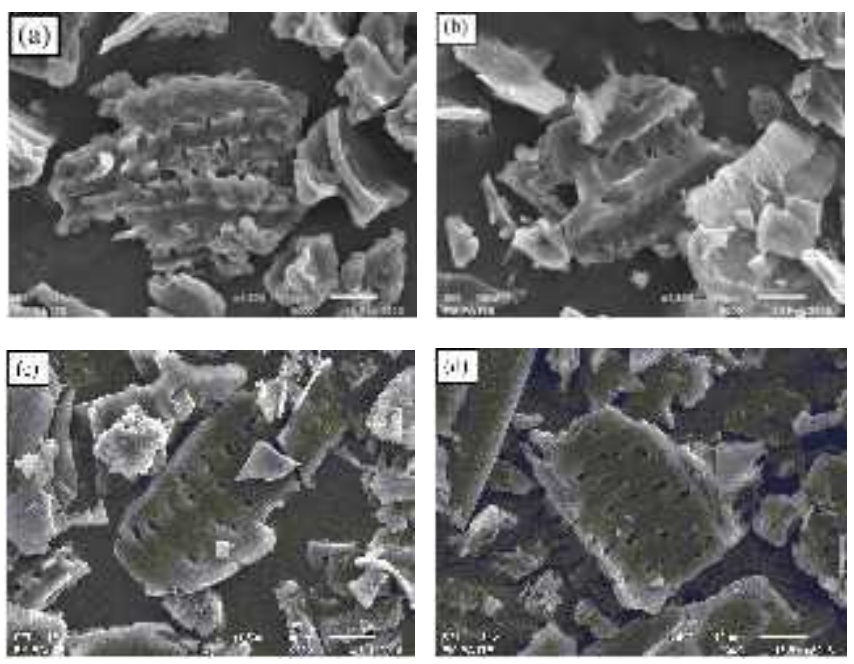

Gambar 3. Hasil SEM dengan Perbesaran 1500x (a) KA360, (b) KA450, (c) KA630, (d) KA720.

Besarnya daya iradiasi gelombang mikro yang diberikan dapat mempengaruhi ukuran pori-pori karbon aktif, semakin besar daya yang diberkan maka pori-pori akan semakin banyak dan terbuka lebar. Poripori yang semakin banyak akan menyebabkan semakin besarnya luas permukaan karbon aktif [8].

Secara keseluruhan pori-pori yang dihasilkan pada karbon aktif dengan variasi daya iradiasi gelombang 
mikro adalah pori-pori yang berukuran makro, sedangkan pori-pori meso dan mikro tidak terlihat. Pori mikro dan meso pada umumnya terletak disekeliling pori makro.

\section{Sifas fisis dan kimia air laut}

Air laut yang telah diberikan karbon aktif dengan variasi daya iradiasi gelombang mikro dilakukan uji sifat fisis dan kimia agar diketahui kualitas air laut setelah diberikan karbon aktif.Uji sifat fisis dan kimia air laut untuk setiap sampel KA360, KA450, KA630 dan KA720 diantaranya yaitu pengukuran pH, suhu, warna, dan salinitas air laut.

\section{pH}

Potential of hydrogen atau yang dikenal dengan $\mathrm{pH}$ adalah derajat keasaman pada air.Air yang baik tidak boleh bersifat asam ataupun basa. Air yang memiliki $\mathrm{pH}$ yang rendah $(<7)$ akan bersifat asam, sedangkan air yang memiliki pH tinggi (> 7) akan bersifat basa [8]. Pengukuran $\mathrm{pH}$ dilakukan dengan menggunakan $\mathrm{pH}$ meter, pada penelitian ini air laut yang telah diberikan karbon aktif memiliki $\mathrm{pH}$ yang hampir sama yaitu pada KA360, KA450, dan KA630 memiliki pH 7,42 dan pada sampel KA720 memiliki $\mathrm{pH} 7,41$. Besarnya $\mathrm{pH}$ pada air laut yang telah diberikan karbon aktif ini tidak jauh berbeda dengan air laut yang belum diberikan karbon aktif yaitu sebesar 7,62, akan tetapi $\mathrm{pH}$ air laut yang telah diberikan karbon aktif menurun dan mendekati $\mathrm{pH}$ netral yaitu 7 meskipun penurunnya tidak terlalu besar. Perubahan $\mathrm{pH}$ ini disebabkan oleh adanya kation pada karbon aktif yang terlarut kedalam air laut [9].

Peraturan menkes 416/MENKES/PER/XI/1990 menyatakan bahawa air dapat digolongkan kedalam air bersih memiliki rentang $\mathrm{pH}$ sebesar 6,5 - 9,0. Berdasarkan Permenkes tersebut, $\mathrm{pH}$ air laut yang telah diberikan karbon aktif dengan variasi daya iradiasi gelombang mikro telah memenuhi standar mutu kualitas air bersih.

\section{Suhu}

Air yang baik adalah air yang memiliki temperatur yang sama dengan temperatur udara yaitu sebesar $20^{\circ} \mathrm{C}-30^{\circ} \mathrm{C}$ [9]. Air laut yang telah diberikan karbon aktif diukur suhunya dengan menggunakan termometer. Air laut yang telah diberikan karbon aktif dengan empat variasi daya iradiasi gelombang mikro memiliki temperatur yang sama yaitu $26^{\circ} \mathrm{C}$, dimana temperatur ini masih tergolong sama dengan temperatur udara, sehingga salah satu sifat fisis air yaitu suhu, air laut yang telah diberikan karbon aktif ini dapat digolongkan pada air yang baik.

\section{Warna}

Warna Air laut dumai sebelum dan setelah diberikan karbon aktif sangat jelas berbeda untuk setiap sampelnya.Air laut yang belum diberikan karbon aktif dapat dilihat pada Gambar 4.

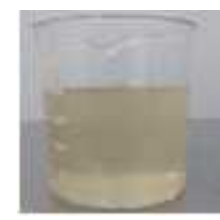

Gambar 4 Air Laut Dumai.

Gambar 4 memperlihatkan air laut Dumai yang belum ditambahkan karbon aktif.Air laut Dumai ini terlihat keruh dan bewarna kekuningan karena masih banyaknya zat pengotor yang terdapat pada air laut Dumai tersebut, setelah pemberian karbon aktif air laut terlihat lebih jernih dibandingkan dengan air laut yang belum ditambahkan karbon aktif.Warna air laut setelah diberikan karbon aktif secara visual dapat dilihat pada Gambar 5.

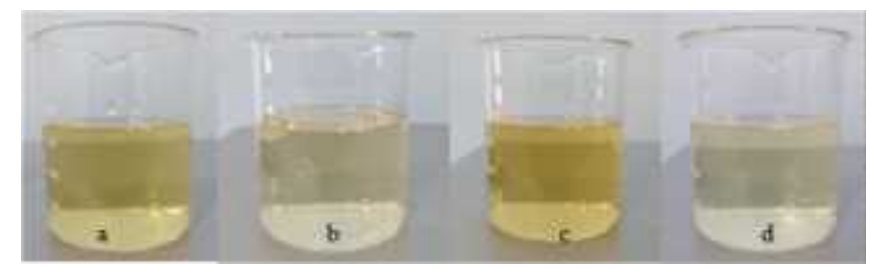

Gambar 5 Air Laut Setelah Diberikan Karbon Aktif (a) KA360, (b) KA450, (c) KA630, (d) KA720. 
Gambar 5 adalah air laut setelah pemberian karbon aktif yang diaduk selama 1 jam dan dilakukan penyaringan, dapat dilihat bahwa setelah pemberian karbon aktif air laut kelihatan lebih jernih dibandingkan sebelum diberikan karbon aktif. Sampel KA720 memiliki warna yang lebih jernih dibandingkan dengan sampel KA360, KA450, dan KA630, hal ini menunjukkan bahwa daya iradiasi gelombang mikro berpengaruh terhadap banyaknya pori-pori karbon akitf, semakin banyak pori-pori karbon aktif maka daya serapnya juga akan semakin besar untuk menyerap zat pengotor sehingga air laut akan semakin jernih, akan tetapi pada sampel KA630 warna air laut terlihat kurang jernih karena pada saat proses iradiasi gelombang mikro timbul percikan api yang menyebabkan sampel terbakar sehingga banyak kandungan abu yang terdapat pada karbon aktif yang menyebabkan penyerapan menjadi tidak optimal.

\section{KESIMPULAN}

Telah berhasil dibuat karbon aktif tongkol jagung dengan proses pra-karbonisasi dan aktivasi kimia menggunakan aktivator $\mathrm{KOH}$ dengan berbantuan iradiasi gelombang mikro. Analisa morfologi permukaan karbon aktif menunjukkan bahwa sampel KA720 memiliki pori-pori yang paling banyak dan telah terbuka lebar. Hasil analisa warna air laut terbaik yaitu pada sampel KA720. Karbon aktif tidak memberikan pengaruh yang signifikan terhadap besar $\mathrm{pH}$, salinitas, dan suhu air laut. Besar $\mathrm{pH}$ air laut setelah diberikan karbon aktif yaitu sebesar 7,41, dan suhu air laut setelah diberikan karbon aktif sebesar $26^{\circ} \mathrm{C}$.

\section{DAFTAR PUSTAKA}

1. Lasabuda, R. (2013). Pembangunan Wilayah Pesisir dan Lautan dalam Perspektif Negara Kepulauan Republik Indonesia. Jurnal Ilmiah Platax, 1(2), 92-101.
2. Mulyanef, Saputra, R. A., Kaidir, \& Duskiardi. (2015). Kaji Ekperimental Alat Pengolahan Air Laut Menggunakan Energi Surya untuk Memproduksi Garam dan Air Tawar. Proceeding Seminar Tahunan Teknik Mesin, 14.

3. Budiyono \& Sumardiono, S. (2013). Teknik Pengolahan Air. Yogyakarta : Graha Ilmu.

4. Lempang, M. (2014). Pembuatan Dan Kegunaan Arang Aktif. Jurnal Balai Penelitian Kehutanan Makassar, 11, 65-80.

5. Kartika, V., Ratnawulan, \& Gusnedi. (2016). Pengaruh Variasi Suhu Karbonisasi Terhadap Mikrostruktur dan Derajat Kristalinitas Karbon Aktif Kulit Singkong sebagai Bahan Dasar GDL. Pillar of Physics, 7, 105-112.

6. Nurdiansah, H. \& Susanti, D. (2013). Pengaruh Variasi Temperatur Karbonisasi dan Temperatur Aktivasi Fisika dari Elektroda Karbon Aktif Tempurung Kelapa dan Tempurung Kluwak Terhadap Nilai Kapasitansi Electric Double Layer Capacitor (EDLC). Jurnal Teknik Pomits, 2(1), 13-18.

7. Widarti, Awitdrus, Farma, R., \& Iwantono. (2016). Pengaruh Daya Iradiasi Gelombang Mikro terhadap Sifat-Sifat Fisika Karbon Aktif Kayu Eucalyptus. Jurnal Komunikasi Fisika Indonesia, 773-780.

8. Hasrianti \& Nurasia. (2016). Analisis Warna, Suhu, pH, dan Salinitas Air Sumur Bor di Kota Palopo. Prosiding Seminar Nasional, 2(1), 747753.

9. Idrus, R., Lapanporo, B. P., \& Putra, Y. S. (2013). Pengaruh Suhu Aktivasi terhadap Kualitas Karbon Aktif Berbahan Dasar Tempurung Kelapa. Prisma Fisika, 1(1), 50-55. 